\title{
P03-010 - IL10 SNPs associated with BD in Western Algeria
}

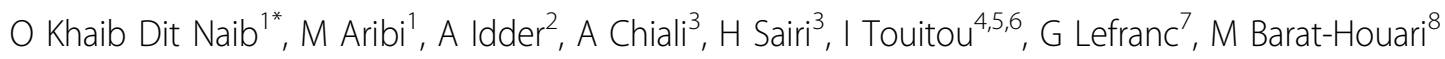 \\ From 7th Congress of International Society of Systemic Auto-Inflammatory Diseases (ISSAID) \\ Lausanne, Switerland. 22-26 May 2013
}

\section{Introduction}

Behcet's disease $(\mathrm{BD})$ is a multisystem inflammatory disease, characterized by recurrent, oral and genital ulceration, skin lesions and uveitis. Several publications in the last decades showed the complex role of genetic factors; recent studies have revealed that SNPs of the IL10 gene promoter are associated with $\mathrm{BD}$ in various populations.

\section{Objectives}

We aimed to test the hypothesis that two SNPs of the IL10 gene promoter (c.-819C $>\mathrm{T}$, rs 1800871 and c. $-592 \mathrm{C}>\mathrm{A}$, rs 1800872) may act as predisposing factors for BD in Algerian patients.

\section{Methods}

Fifty one BD patients and 96 unrelated controls from Western Algeria were genotyped for the two SNPs by direct sequencing. Allele and genotype distributions were compared between cases and controls, using Chi2 or Fisher's exact tests.

\section{Results}

The minor alleles c.-819T and c.-592A, were significantly more frequent (i) in BD patients than in controls $(44 \%$ versus $27 \%, p=0.003, \mathrm{OR}=2.18$; $95 \% \mathrm{CI} 1.33,3.90)$ and (ii) in patients with genital ulcers or skin lesions than those without $(\mathrm{OR}=2.28, p=0.002,95 \%$ CI $1.10,1.60$ and $\mathrm{OR}=2.18, p=0.0035,95 \% \mathrm{CI} 1.27,3.72$, respectively).

\section{Conclusion}

Our results showed that two investigated SNPs play a role in $\mathrm{BD}$ and in most of its related phenotypes in the population of Western Algeria. These observations are consistent with those reported for other ethnic groups, but need to be confirmed in a larger sample.

${ }^{1}$ Immunology, Tlemcen University, Tlemcen, Alger

Full list of author information is available at the end of the article

\section{Competing interests}

None Declared.

\section{Authors' details}

${ }^{1}$ Immunology, Tlemcen University, Tlemcen, Alger. ${ }^{2}$ Ophtalmology, Hamou Boutlelis Clinic, Alger. ${ }^{3}$ Dermatology, Chu, Oran, Algeria. ${ }^{4}$ INM U844, Inserm, France. ${ }^{5}$ Montpellier University, France. ${ }^{6}$ Genetic, Chru de Montpellier, France. ${ }^{7}$ Immunogenetic, CNRS UPR1142 IGH, France. ${ }^{8}$ Genetic, Chru, Montpellier, France.

\section{Published: 8 November 2013}

\section{doi:10.1186/1546-0096-11-S1-A205}

Cite this article as: Khaib Dit Naib et al:: P03-010 - IL10 SNPs associated with BD in Western Algeria. Pediatric Rheumatology 2013 11(Suppl 1):A205.
Submit your next manuscript to BioMed Central and take full advantage of:

- Convenient online submission

- Thorough peer review

- No space constraints or color figure charges

- Immediate publication on acceptance

- Inclusion in PubMed, CAS, Scopus and Google Scholar

- Research which is freely available for redistribution
C Biomed Central

\section{Biomed Central}

